\title{
BIOSURFACTANTS PRODUCTION BY YEASTS USING SOYBEAN OIL AND GLYCEROL AS LOW COST SUBSTRATE
}

\section{Fábio Raphael Accorsini ${ }^{1 *}$, Márcia Justino Rossini Mutton ${ }^{2}$, Eliana Gertrudes Macedo Lemos ${ }^{2}$, Maria Benincasa ${ }^{1}$}

${ }^{1}$ Departamento de Biologia Aplicada à Agropecuária, Universidade Estadual Paulista, Jaboticabal, SP, Brasil; ${ }^{2}$ Departamento de Tecnologia, Universidade Estadual Paulista, Jaboticabal, SP, Brasil.

Submitted: May 07, 2010; Returned to authors for corrections: July 19, 2011; Approved: January 16, 2012.

\begin{abstract}
Biosurfactants are bioactive agents that can be produced by many different microorganisms. Among those, special attention is given to yeasts, since they can produce many types of biosurfactants in large scale, using several kinds of substrates, justifying its use for industrial production of those products. For this production to be economically viable, the use of residual carbon sources is recommended. The present study isolated yeasts from soil contaminated with petroleum oil hydrocarbons and assessed their capacity for producing biosurfactants in low cost substrates. From a microbial consortium enriched, seven yeasts were isolated, all showing potential for producing biosurfactants in soybean oil. The isolate LBPF 3, characterized as Candida antarctica, obtained the highest levels of production - with a final production of $13.86 \mathrm{~g} / \mathrm{L}$. The isolate LBPF 9, using glycerol carbon source, obtained the highest reduction in surface tension in the growth medium: approximately $43 \%$ of reduction after 24 hours of incubation. The products obtained by the isolates presented surfactant activity, which reduced water surface tension to values that varied from $34 \mathrm{mN} / \mathrm{m}$, obtained from the product of isolates LBPF 3 and 16 LBPF 7 (respectively characterized as Candida antarctica and Candida albicans) to $43 \mathrm{mN} / \mathrm{m}$ from the isolate LPPF 9, using glycerol as substrate. The assessed isolates all showed potential for the production of biosurfactants in conventional sources of carbon as well as in agroindustrial residue, especially in glycerol.
\end{abstract}

Key words: Yeast, Biosurfactants, Glycerol, Soybean oil

\section{INTRODUCTION}

The main propriety of biosurfactants is to reduce surface and interfacial tensions by its accumulation in the interface between non-mixable fluids, increasing solubility and mobility of hydrophobic or organic compounds. Microorganisms which produce biosurfactants are isolated from sites which present or were contaminated by petroleum hydrocarbons. This usually occurs since, in nature, biosurfactants play a physiologic role in increasing bioavailability of hydrophobic molecules which are involved in cellular signaling and differentiation processes, which facilitate the consuming of carbon sources present in soil (33).

A great quantity and diversity of biosurfactants is

*Corresponding Author. Mailing address: Departamento de Biologia Aplicada à Agropecuária, Universidade Estadual Paulista, CEP: 14884-900, Jaboticabal SP - Brasil.; Tel: +55 (016) 3209 2620.; E-mail: fraccorsini@yahoo.com.br 
described in published literature - most of those being originated by bacteria. According to Shephard et al. (32), most of these bioproducts would not be adequate for use in some industrial branches of production such as in the production of foodstuffs, because of their potential pathogenic nature. On the other hand, yeasts have been studied for the production of these substances with great success, especially due to their GRAS (generally regarded as safe) status. Microorganisms which boast a GRAS status would not present risk of inducing toxicity and pathogenic reactions - a fact that increases the range of possible uses for biosurfactants obtained from these microorganisms (15).

Yeasts are also known for producing biosurfactants in higher concentrations than bacteria, which is an advantage regarding these microorganisms. However, they have not being widely used yet due to high cost concerning their obtaining, making them economically impracticable for production in industrial scale (10) and (11).

One possible strategy for reducing production costs is the use of alternative substrates, such as agricultural waste, or that produced by the food industries - which are known for containing high levels of carbohydrates and of lipids - both of which are necessary for substrates for the production of biosurfactants $(5,14)$. Some examples of residue substrates would be different types of pre-used oils, soapstock, waste borne from the processing of vegetables such as potatoes and cassava, sugar cane molasses and, recently, glycerol, a residue originated from the production of biodiesel fuel (11).

When using residual substrates in processes for obtaining biosurfactants, production costs can be greatly reduced, and the volume of waste (which would be someway dumped into the environment) is also smaller. Furthermore, the final product generated is of high aggregated value.

The present work was done to assess, isolate and select yeast strains which present a potential for the production of biosurfactants, and to investigate the capacity of these isolates in using low cost sources of carbon (such as soybean oil and glycerol) in this production.

\section{MATERIALS AND METHODS}

\section{Isolation of the microorganisms}

There were used microorganisms isolated from a microbial consortium obtained from petroleum hydrocarbons contaminated soil samples originated from the waste of a car repair shop. After the 20th enrichment of this microbial consortium, dilutions were done until $10^{-6}$ using a saline solution, and from that procedure, morphologic differentiation of the produced microorganisms was done, as shown by Van der Valt \& Yarron (35), composed of glucose (20 g/L), peptone $(1 \mathrm{~g} / \mathrm{L})$, yeast extract $(0.5 \mathrm{~g} / \mathrm{L})$, and $\operatorname{Agar}(1.7 \mathrm{~g} / \mathrm{L})$.

For each $100 \mathrm{~mL}$ of the sterile culture medium, $1 \mathrm{~mL}$ of ampicilin was added. A $0.1 \mathrm{~mL}$ inoculum of each dilution was added to Petri dishes with one repetition of each, and, afterwards, those were incubated at $30^{\circ} \mathrm{C}$ for $72 \mathrm{~h}$. From the inoculated dishes, yeasts were isolated by morphologic differentiation, considering differences such as: color, borders and size of the colonies, texture, surface appearance and elevation. Those obtained isolates were transferred and stocked in GYMP media, described by Lodder (25), composed of glucose $(20 \mathrm{~g} / \mathrm{L})$, malt extract $(1 \mathrm{~g} / \mathrm{L})$, yeast extract $(0.5$ $\mathrm{g} / \mathrm{L})$, monobasic sodium phosphate $(0.20 \mathrm{~g} / \mathrm{L})$, and Agar (1.7 $\mathrm{g} / \mathrm{L})$.

Samples of the isolates were sent to the Laboratory of Microorganism and Plant Biochemistry (Laboratório de Bioquímica de Microrganismos e Plantas) at UNESPFCAVJ for their molecular characterization. The extraction of the genomic DNA of the isolated yeasts was done according to the method suggested by Hoffman \& Winston, ( 36 ). For the amplification of the gene 18S, ITS1-5,8S-ITS2 of the isolates, the pair of primers ITS1/ITS4 was used suggested by WHITE et al. (19). The sequences obtained were compared to the ones deposited in the "NCBI" (National Center for Biotecnology Information). Blast (Basic Local Alignment Search Tools) was 
used as the tool for the comparison of the sequences. $(12,13)$

\section{Characterization of the isolates in chromogenic CHROMagar ${ }^{\mathrm{TM}}$ Candida medium.}

The CHROMagar ${ }^{\mathrm{TM}}$ Candida (Microbiology, France) media was prepared according to the manufacturer's instructions; 4.8 grams of the dehydrated medium was added to $100 \mathrm{~mL}$ distilled water. Each isolate was sub-cultivated in this media and then incubated at $30^{\circ} \mathrm{C}$ for $48 \mathrm{~h}$.

Readings of the cultivated dishes and the interpretation of the results were done by observation of morphology and pigmentation of the obtained colonies (16).

\section{Production of biosurfactants}

The inoculum was obtained from the stock culture of each of the selected yeast isolates. Each of those was transferred to a $500 \mathrm{~mL}$ glass flask containing $100 \mathrm{~mL}$ of the medium as described by Kitamoto et al. (23), which contained $\mathrm{KH}_{2} \mathrm{PO}_{4}(3$ $\mathrm{g} / \mathrm{L})$, yeast extract $(10 \mathrm{~g} / \mathrm{L}), \mathrm{NaNO}_{3}(30 \mathrm{~g} / \mathrm{L})$, and $\mathrm{MgSO}_{4}(3$ $\mathrm{g} / \mathrm{L})$, and $4 \%$ glucose as carbon source. This pre-inoculum was cultivated under agitation at $30^{\circ} \mathrm{C}, 200 \mathrm{rpm}$ for $48 \mathrm{~h}$.

Fermentative media was prepared in a $500 \mathrm{~mL}$ glass flask containing $100 \mathrm{~mL}$ of the medium as described by Kitamoto et al. (23), composed of $\mathrm{KH}_{2} \mathrm{PO}_{4}(2 \mathrm{~g} / \mathrm{L})$, yeast extract (10 g/L), $\mathrm{NaNO}_{3}(20 \mathrm{~g} / \mathrm{L}), \mathrm{MgSO}_{4}(2 \mathrm{~g} / \mathrm{L})$, and $4 \%$ glucose from the carbon source (soybean oil or glycerol). Five percent of the inoculum was added to the media and, immediately afterwards, incubated at $200 \mathrm{rpm}$ at $30^{\circ} \mathrm{C}$ for 7 days.

\section{Analytical methods}

Samples from the fermentative media were taken before the addition of the inoculum. After inoculation, aliquots were collected at 24 hour intervals for assessment of fermentation parameters, and were submitted to analyses of $\mathrm{pH}$, surface tension and dry biomass.

Ten milliliters of the fermentative medium was aseptically collected, and then centrifuged at $4.000 \mathrm{rpm}$ for $20 \mathrm{~min}$. The obtained supernatant was used for assessment of $\mathrm{pH}$ and surface tension. The sediment containing the cells was used for assessment of dry biomass.

All analyses were repeated three times and the presented results are from the arithmetic means of the results obtained in the study.

\section{Determination of surface tension}

The production of biosurfactants was monitored by the measurement of the surface tension in the media according to the "ring method" by De Nöuy, using a KRÜSS K6 tension meter. The du Noüy ring method is one technique by which the surface tension of a liquid can be measured. The method involves slowly lifting a ring, often made of platinum, from the surface of a liquid. The force required to raise the ring from the liquid's surface is measured and related to the liquid's surface tension, (29)

\section{Determination of Dry biomass}

Cell growth was assessed by the quantification of dry mass. Cell residue was re-suspended in $10 \mathrm{~mL}$ of distilled water and centrifuged under the same conditions as described above. The supernatant was discarded and $10 \mathrm{~mL}$ ethyl acetate was added to the cell residue and was submitted to centrifugation again. The produced supernatant was also discarded and the remaining cells were transferred to recipients which had been previously weighted. Afterwards, those were dried in incubators at $100^{\circ} \mathrm{C}$ and once more weighted, obtaining the values of dry biomass.

\section{Extraction and quantification of the obtained biosurfactants.}

The products obtained were extracted as according to Jing et al. (21), and Kitamoto et al. (24). The media free of cells were submitted to extraction by shaking using ethyl acetate at the same volume and evaporated under vacuum at $50^{\circ} \mathrm{C}$ for subtraction of the substrate. Afterwards, those were rinsed with 
hexane and once more evaporated at $50^{\circ} \mathrm{C}$ in a vacuum pump, thus obtaining the extracts which were quantified by weight.

\section{Analysis of the surfactant activity of the obtained products.}

To assess the efficacy of the obtained products in reducing the surface tension, there were added aliquots of $0.02 \mathrm{~g}$ of the product (the ideal concentration at which the maximum reduction of surface tension that has been observed in many other studies) to $20 \mathrm{ml}$ of ultra-pure water. The evaluation was done every 24 hours until the end of the 168 hours of cultivation.

\section{RESULTS AND DISCUSSION}

Isolation and assessment of capacity for production of biosurfactants.

The enrichment and following isolation of yeasts allowed the obtaining of seven yeast isolates denominated as following: LBPF 1, LBPF 3, LBPF 7, LBPF 9, LBPF 10, LBPF 14 and LBPF 15.

Initially, all of the seven obtained isolates were tested to determine their capacity for producing biosurfactants using soybean oil as a carbon source. That assessment was done by the analysis of the surface tension value in the medium; which was measured, initially, at $47 \mathrm{mN} / \mathrm{m}$.

The reduction of that tension is used as primary criteria in the selection of microorganisms which produce biosurfactants, although emulsifying and dispersing agents do not necessarily possess ability to reduce surface tension (33, 37). Figure 1 illustrates the reduction in surface tension of media and the cell growth in the isolates according to time of incubation. Media inoculated with all seven isolates, after 24 hours of incubation, presented reductions in surface tension from the initial value of 47 $\mathrm{mN} / \mathrm{m}$ to $31 \mathrm{mN} / \mathrm{m}$ (LBPF 1), $29 \mathrm{mN} / \mathrm{m}$ (LBPF 3), $32 \mathrm{mN} / \mathrm{m}$ (LBPF 7), $32 \mathrm{mN} / \mathrm{m}$ (LBPF 9), $38 \mathrm{mN} / \mathrm{m}$ (LBPF 10), $32 \mathrm{mN} / \mathrm{m}$ (LBPF 14) and $34 \mathrm{mN} / \mathrm{m}$ (LBPF 15). Those reductions maintained values that were close to those that had been observed at $24 \mathrm{~h}$ of incubation, until the end of the evaluation period.

The greatest reductions in surface tension in media after $24 \mathrm{~h}$ of cultivation occurred when the cells were in exponential growth. That fact was observed by Rufino et al. (30) when studying the production of biosurfactants by Candida lipolytica. Other authors verified that the greatest reduction in surface tension occurred during the phase of exponential cell growth. Beginning at values of $50 \mathrm{mN} / \mathrm{m}$, minimum values of $30 \mathrm{mN} / \mathrm{m}$ were obtained in $24 \mathrm{~h}$ of cultivation. Souza-Sobrinho (34), studying the production of biosurfactants by Candida sphaerica using soapstock as source of carbon, also obtained similar results, where at 24 hours of cultivation he observed a reduction in surface tension of their media from $30 \mathrm{mN} / \mathrm{m}$ to minimum values of $26 \mathrm{mN} / \mathrm{m}$. According to Amaral et al. (2), most biosurfactants are produced when the cultures attain the stationary phase of growth, although some species can present production during their exponential growth phase.

The data obtained from the production of biosurfactants by the different isolates in soybean oil after 168 hours is illustrated in Table 1.

Tabel 1. Parameters of biosurfactant production by the isolates using soybean oil as substrate (mean and standard deviation of three replicates), after the final 168 hours of cultivation.

\begin{tabular}{|c|c|c|c|c|c|c|c|}
\hline \multirow[t]{2}{*}{ Parameters } & \multicolumn{7}{|c|}{ Microorganisms } \\
\hline & LBPF 1 & LBPF 3 & LBPF7 & LBPF 9 & LBPF 10 & LBPF 14 & LBPF 15 \\
\hline biomass & 12,22 & 18,91 & 16,78 & 9,55 & 12,31 & 16,2 & 13,8 \\
\hline$(\mathrm{g} / \mathrm{L})$ & $\pm 0,14$ & $\pm 0,04$ & $\pm 0,03$ & $\pm 0,04$ & $\pm 0,07$ & $\pm 0,5$ & $\pm 0,07$ \\
\hline & 9,13 & 13,86 & 7,98 & 3,0 & 4,4 & 4,2 & 4,9 \\
\hline $\mathrm{BS}^{1}(\mathrm{~g} / \mathrm{L})$ & $\pm 0,02$ & $\pm 0,11$ & $\pm 0,13$ & $\pm 0,07$ & $\pm 0,10$ & $\pm 0,09$ & $\pm 0,10$ \\
\hline & 0,75 & 0,73 & 0,48 & 0,31 & 0,36 & 0,26 & 0,4 \\
\hline $\mathrm{Y} p / \mathrm{b}^{2}(\mathrm{~g} / \mathrm{g})$ & $\pm 0,01$ & $\pm 0,01$ & $\pm 0,01$ & $\pm 0,01$ & $\pm 0,01$ & $\pm 0,01$ & $\pm 0,01$ \\
\hline & 39 & 38 & 39 & 32 & 39 & 37 & 39 \\
\hline $\mathrm{TS}^{3} \mathrm{mN} / \mathrm{m}$ & $\pm 0,82$ & $\pm 1,37$ & $\pm 0,98$ & $\pm 0,41$ & $\pm 0,75$ & $\pm 0,75$ & $\pm 0,52$ \\
\hline 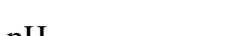 & 4,87 & 4,51 & 4,41 & 4,51 & 4,35 & 3,99 & 4,72 \\
\hline $\mathrm{pH}$ & $\pm 0,21$ & $\pm 0,17$ & $\pm 0,1$ & $\pm 0,07$ & $\pm 0,08$ & $\pm 0,11$ & $\pm 0,08$ \\
\hline
\end{tabular}



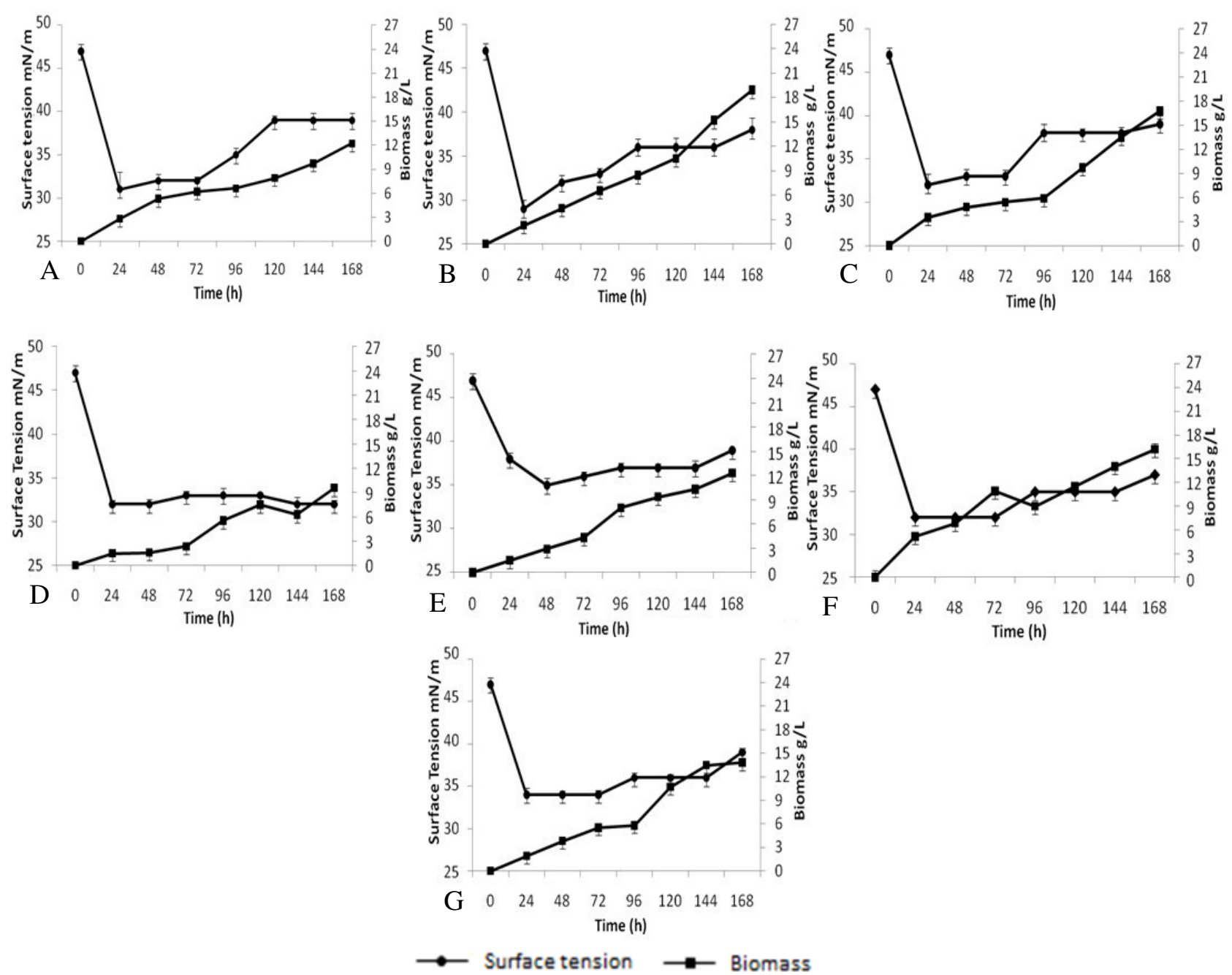

Figure 1. Reduction of surface tension in media for cultivation and cell growth versus time period of incubation for the different isolates using soybean oil as substrate. A (LBPF 1); B (LBPF 3); C (LBPF 7), D (LBPF 9); E (LBPF 10); F (LBPF 14); G (LBPF 15). Each error bar represents S.D. out of three replicate experiments

Beginning at a $\mathrm{pH}$ value of 5.78 , found final values varied from 3.99 to 4.87 . The $\mathrm{pH}$ values were found to be increased after 96 hours of cultivation, and together with that increase, a slight increase in the values of surface tension in the media was also observed. According to Bednarsk et al. (4), constant acidity found in the culture medium is a parameter which correlates to the efficacy of glicolipid synthesis by yeasts such as $C$. antarctica and C. apicola. A greater production of glycolipids is attained to the control and maintenance of $\mathrm{pH}$ values during the assays. However, when $\mathrm{pH}$ is not adjusted in the media, a negative effect is exerted on the efficacy of the synthesis of those products.

Cell biomass increased throughout the process for all of the different isolates, attaining, at the end, values ranging from 9.55 g/L for LBPF 9, to $18.91 \mathrm{~g} / \mathrm{L}$ for LBPF 3. Final surface tension values in the media that used soybean oil as a carbon source varied from 32 to $39 \mathrm{mN} / \mathrm{m}$. Concerning the different isolates, isolate LBPF 3 presented the greatest cell growth and the highest final product concentration $(13,86 \mathrm{~g} / \mathrm{L})$. However, the highest coefficient of yield of the biosurfactant versus cell 
concentration was obtained by isolate LBPF 1.

The results obtained in those assays were similar to those obtained by Daverey et al. (9) - who studied the production of biosurfactants by Candida bombiculata in different media, and obtained a production of $12.67 \mathrm{~g} / \mathrm{L}$, and a final cell growth of $17.95 \mathrm{~g} / \mathrm{L}$, when cultivating the yeast in media which used soybean oil as its carbon source. Costa et al. (7) used burnt soybean oil in the production of biosurfactants by isolates of Pseudomonas, and obtained an average production of $6.1 \mathrm{~g} / \mathrm{L}$, with reduction of surface tension in $35.5 \mathrm{mN} / \mathrm{m}$ to values varying from 31 to $33 \mathrm{mN} / \mathrm{m}$. Haba et al. (17) verified a reduction in surface tension in media from $57 \mathrm{mN} / \mathrm{m}$ to values varying from $35 \mathrm{mN} / \mathrm{m}$ to $40 \mathrm{mN} / \mathrm{m}$, using low cost substrates (oil used for frying food) by different species of yeast.

The assessed isolates presented viable potential for the synthesis of biosurfactant substances when using soybean oil as substrate in their cultivation. After checking the capacity for producing biosurfactants by the isolates, assays were done using glycerol as source of carbon for the production of biosurfactants.

Starting with a surface tension of $68 \mathrm{mN} / \mathrm{m}$, it was observed a reduction in value in the media for all of the studied isolates, although only isolate LBPF 9 obtained significant results as a potential producer of biosurfactants in that residue.

Figure 2 illustrates the cell development and the reduction in surface tension of the medium inoculated with this isolate. The surface tension in the medium was reduced (after 24 hours of incubation) to $39 \mathrm{mN} / \mathrm{m}$, attaining a reduction of approximately $43 \%$. That was the largest reduction obtained in the assay when comparing the two different carbon sources.

Figure 2. Reduction of surface tension and cell growth of the medium using glycerol as inoculated source of carbon, with isolate LBPF9. Each error bar represents S.D. out of three replicate experiments.

that obtained with the media using soybean oil as source of carbon. The largest reduction in surface tension also occurred during the phase of exponential growth. The results obtained by this isolate were found to be similar to those obtained by Ciapina et al. (6), who studied the production of biosurfactants by Rhodococcus erythropolis, using glycerol as carbon source. Those authors obtained a production of $1.7 \mathrm{~g} / \mathrm{L}$. Crasto (8), concentration was of $0.75 \mathrm{~g} / \mathrm{g}$, a value that seen to be similar to 
assessing the production of rhamnolipids by bacteria isolated from a petroleum oil extraction well and using glycerol as carbon source, reported a reduction in surface tension in media from initial values of $68 \mathrm{mN} / \mathrm{m}$ to final values that varied from 44.6 to $53.7 \mathrm{mN} / \mathrm{m}$, with the final volumes recovered varying from 0.33 to $1.9 \mathrm{~g} / \mathrm{L}$.

Although the produced biosurfactants by the isolates using soybean oil were in higher concentrations than those cultivated in glycerol, preliminary results of isolate LBPF 9 indicate the capacity of this residue for its use as a carbon source in the production of biosurfactants. The smallest production with glycerol was expected since, according to Nitschke et al. (27), hydrophilic carbon sources such as glycerol present lower yield of biosurfactants when compared to hydrophobic sources such as soybean oil.

In their study, using Pseudomonas aeruginosa, those authors verified that the oil substrates presented a production of rhamnolipids $64 \%$ larger than the non oily substrates. Furthermore, the media as well as the growth conditions constitute basic factors to be considered in a preliminary assessment of bioactive agent production capacity by yeasts. Therefore, future studies regarding optimization of this process are of great importance.

Isolate LBPF 9 demonstrated capacity for producing biosurfactants from residue derived from the production of biodiesel fuel (glycerol), calling attention to this carbon source as a potential alternative for reducing costs in the production of

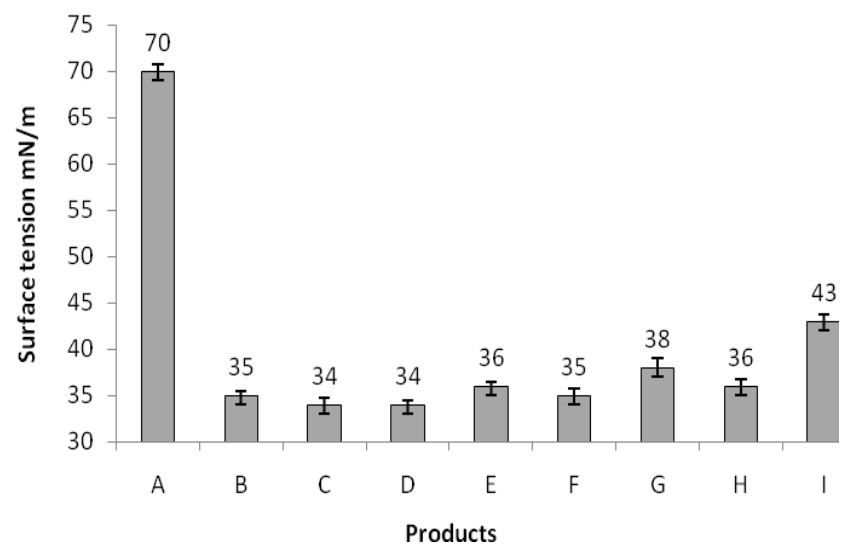

biosurfactants. Considering the usual high cost for producing biosurfactants, the isolation of microorganisms which show potential for this production and the use of low cost substrates could present themselves as viable strategies for obtaining these substances.

\section{Surfactant activity of the obtained product}

The product obtained from the assessed isolates presented high surfactant activity, reducing surface tension in water to values close to $30 \mathrm{mN} / \mathrm{m}$. Then, the capacity for reducing surface tension was observed in the presence of the obtained bioproducts. Initial surface tension of water was measured at $70 \mathrm{mN} / \mathrm{m}$ and was reduced to values that varied from $34 \mathrm{mN} / \mathrm{m}$ (for the product obtained by isolates LBPF 3 and LBPF 7 using soybean oil as substrate), to $43 \mathrm{mN} / \mathrm{m}$ (for the product obtained by isolate LBPF 9 using glycerol as substrate). Those values were found to be similar to those described for other biosurfactants produced by yeasts grown in vegetable oils in the following studies: Candida lipolytica $31 \mathrm{mN} / \mathrm{m}$, Rufino (30); Candida glabrata $31 \mathrm{mN} / \mathrm{m}$, Sarrubo (31); Candida antartica $35 \mathrm{mN} / \mathrm{m}$, Adamczak \& Berdnarski (1).

The results reported in the present study showed, therefore, that the products obtained from the different isolates possess surfactant activity. Figure 3 illustrates the reduction in surface tension of water in the presence of the obtained product, purified, after 168 hours of cultivation.

Figure 3. Reduction of surface tension of water in the presence of different products. A - Pure water, BLBPF 1, C- LBPF 3, D- LBPF 7, E- LBPF 9, F- LBPF 10,G- LBPF 14, H- LBPF 15 and I- LBPF 9 obtained in glycerol. Those values express the S.D. out of three replicate experiments. 
Characterization of the isolates with the use of the chromogenic CHROMagar ${ }^{\mathrm{TM}}$ Candida medium

The molecular characterization showed incomplete results. Out of the seven isolates, only LBPF 1, LBPF 3 e LBPF 7 succeeded in their sequencing and were characterized as belonging to Candida genus. Done to the similarity of the obtained sequences, there was doubt if either the isolates were the same or the methods adopted for the identification were not efficient. Thus, chromogenic media method was used to identify different species of Candida genus.

Differentiation of the isolates and the characterization of the species were possible by cultivation in chromogenic CHROMagar $^{\mathrm{TM}}$ Candida medium. The isolates LBPF 1, LBPF 3 e LBPF 15 were characterized as being Candida tropicalis, since they presented a blue coloration after 48 hours of incubation in that medium. The LBPF 7 isolate was characterized as being Candida albicans presenting a metallic green coloration; LBPF 10 isolate was characterized as being Candida glabrata presenting a lilac color. Isolates LBPF 9 and LBPF 14 did not present growth in the media, even after 96 hours of incubation, therefore their characterization was not possible. However, it could be concluded that they do not belong to the Candida genus.

CHROMagar $^{\mathrm{TM}}$ Candida is a chromogenic cultivation medium which allows the presumptive identification of yeasts since it contains a lot of enzyme substrates that, when hydrolyzed by the corresponding hexaminidases, allows the identification of the yeast according to the pigmentation exhibited by the colonies formed in a time period of 24 to 48 hours (28). This medium indicates metallic green for $C$. albicans, blue for $C$. tropicalis, lilac for C. glabrata and a white coloration for the other species of the Candida genus (32).

A lot of authors verified the efficacy of this medium for identification of the species of Candida when compared to traditional biochemical and molecular methods. Yucesoy \& Marol (38) verified that, - of 169 isolates of C. albicans, - 168 presented light green colonies when grown in CHROMagar ${ }^{\mathrm{TM}}$ Candida, and that, out of 33 isolates of $C$. tropicalis studied, 32 produced colonies of light blue coloring. Araujo et al. (3) verified $100 \%$ of concurrence for isolates of C. glabrata, which presented lilac colored colonies.

Species of Candida have been widely used for the fermentation of insoluble substrates and are frequently reported as producers of emulsifying agents (30). Sarubbo et al. (31) demonstrated the production of a biosurfactant by Candida glabrata when cultivated in n-Hexadecane. Kim et al. (22) isolated twenty yeast halo forming colonies from contaminated soil samples using agar dishes covered with crude oil. The isolated colonies were cultivated in the isolating fluid containing n-Hexadecane, soybean oil or glucose as carbon source, and the production of biosurfactants was verified. Most of the strains were identified as belonging to the Candida genus. Konish et al. (25), (using Candida batistae), studied the production of glycolipids in residual media. Hirata et al. (18) studied the production of sophorolipid biosurfactants in low cost media using the non pathogenic yeast Candida bombicola.

The large variety of species existing in the genus also exerts influence on the type of biosurfactant obtained.

For instance Candida bombicola, Candida petrophilum and Candida bogoriensis were reported as producers of sophorolipids, Candida antarctica as a producer of mannosylerythritol lipids, Candida tropicalis and Candida lipolytica IA 1055 as producers of the complex carbohydrate protein - lipid and many other species such as Candida ingens, Candida utilis, Candida valida and Candida boleticola as producers of biosurfactants not yet classified (20).

The range of yeast species that belong to the Candida genus allows the possibility of a wide spectrum of products which could be produced. Those microorganisms, besides being easily isolated, present a wide variety regarding the ability of using different substrates for the production of biosurfactants, including those composed of residue (waste) and other also low cost substrates. 


\section{REFERENCES}

1. Adamczak, M.; Bednarski, W. (2000). Influence of medium composition and aeration on the synthesis of surfactants produced by Candida Antarctica. Biotechnogy Letters. 22, 313-316.

2. Amaral, P.F.F.; da Silva, J.M.; Lehocky, B.M.; Barros-Timmons, A.M.V.; Coelho, M.A.Z.; Marrucho, I.M.; Coutinho (2006). Production and characterization of a bioemulsifier from Yarowia lipolytica. Process Biochemystry. 41, 1894-1898.

3. Araújo, M.A. (2006). Caracterização molecular de espécies de Candidas Isoladas de portadores de AIDS e portadores de Câncer atendidos em Hospitais escola Maceió. Recife, Brasil, 115p. (Ph.D Thesis. Universidade Federal de Pernanbuco).

4. Bednarski, W.; Adamcsak, M.; Tomasik, J.; Plaszczyk, M. (2004). Application of oil refinery waste in the biosynthesis of glycolipids by yeast. Bioresource Technology, 95, 15-18.

5. Benincasa, M.; Accorsini, F.R. (2007). Rhamnolipid Produced from Agroindustrial Wastes Enhances Hydrocarbon Biodegradation in Contaminated Soil. Current Microbiol. 99, 3843-3849.

6. Ciapina, E.M.P.; Melo, W.C.; Santa Anna, L.M.M.; Santos, A.S.; Freire, D.M.G.; Pereira Jr, N. (2006). Biosurfactant Production by Rhodococcus erythropolis Grown on Glycerol as Sole Carbon Source. Appl Biochem Biotechnol, 880, 129 -132.

7. Costa, S.G.V.A.O.; Nitschke, M.; Contiero, J. (2008). Produção de biotensoativos a partir de resíduos de óleos e gorduras. Ciênc. Tecnol. Aliment. 28, 34-38.

8. Crasto, C.J.T.L. (2005). Avaliação da produção de raminolipidios por bactérias isoladas de poços de petróleo. Pernambuco, Brasil, 53p. (M.Sc. Dissertation. Universidade Federal de Pernambuco).

9. Daverey, A.; Pakshirajan K. (2009). Production of sophorolipids by the yeast Candida bombicola using simple and low cost fermentative media. Food Res. Internat. 42, 499-504.

10. De Lima, C.J.B.; Contiero, J. (2009). Use of Soybean Oil Fry Waste for Economical Biosurfactant Production by Isolated Pseudomonas aeruginosa Using Response Surface Methodology. Curr. Trend. Biotechnol. Pharm. 3, 162-171.

11. Desai, J.D.; Banat, I.M. (1997). Microbial production of surfactants and their comercial application. Microbiol. Mol. Biol. Rev. 61, 47-64.

12. Ewing, B.; Green, P. (1998a). Base-calling of automated sequencer traces using phred. II. Error probabilities, Genome Res. 8:186-194.

13. Ewing, B.; Hillier, L.; Wendl, M.C.; Green, P. (1998b). Base-calling of automated sequencer traces using phred. I. Accuracy assessment, Genome Res. 8:175-185.

14. Felse, P.A.; Shah, V.; Chan, J.; Rao, K.J.; Gross, R.A. (2007). Sophoroplid biosyntesis by Candida bombicola from industrial fatty acid residues. Enzyme Microb. Technol. 40, 316-323.
15. Fontes, G. C.; Amaral, P. F. F. E.; Coelho, M, A, Z. (2008). Produção de biossurfactante por levedura. Quimica Nova. 40, 316-323.

16. García-Martos, P.; García-Agudo, R.; Hernándes-Molina, J.M.; Marín, P.; Tarello, E.; Mira, J.(1998). Unstructured kinetic model for sophorolipid production by Candida bombicola. Rev Iberoam Micol. 15, 131-135.

17. Haba, E.; Espuny, M.J.; Busquets, M.; Manresa, A. J. (2000). Screening and production of rhamnolipids by Pseudomonas aeruginosa 47T2 NCIB 40044 from waste frying oils. Appl. Microbiol. 88, 379-387.

18. Hirata,Y.; Yukaoda M., Igarashi, K.; A. Masakisugiura, T. (2009). Novel characteristics of sophorolipids, yeast glycolipid biosurfactants, as biodegradable low-foaming surfactants. Saraya Co Ltd. 26, 24-12.

19. Hoffman, C. S .and F. Winston. (1987) A ten-minute DNA preparation from yeast efficiently releases autonomous plasmids for transformation of Escherichia coli. Gene 57: 267-272.

20. Ilori, M. O; Sunday A; Adebusoye, Adedoyin; C. O.J.O. (2008) Isolation and characterization of hydrocarbon-degrading and biosurfactantproducing yeast strains obtained from polluted lagoon water. World $J$ Microbiol Biotechnol 24, 2539-2545.

21. Jing, C.; Xin, S.; Hui, Z.; Yinbo, Q. (2007). Production, structure elucidation and anticancer properties of sophorolipid from Wickerhamiella domercqiae .Enzyme Microb. Technol. 39, 501-506.

22. Kim, H. S.; Jeon, J. W.; Kim, B. H.; Ahn, C. Y.; Mock OH, H.; Yoon, B. D. (2006). Extracellular production of a glycolipid biosurfactant, mannosylerythritol lipid, by Candida sp. SY16 using fed-batch fermentation. Appl. Microbiol. Biotechnol, 70, 391-396.

23. Kitamoto, D.; Haneishi, K.; Nakahara, T.; Tabuchi, T. (1990). Production of Mannosylerythritol Lipids by Candida antarctica from Vegetable Oils Agric. Biol. Chem. 54, 37-40.

24. Kitamoto, D.; Ikegami, T.; Suzuki, G.T.; Sasaki, A.; Takeyama, Y.; Idemoto, Y.; Koura, N.; Yanagishita H. (2001). Microbial conversion of $n$-alkanes into glycolipid biosurfactants, mannosylerythritol lipids, by Pseudozyma (Candida Antarctica) .Biotechnol. Lett. 23, 1709-1714.

25. Konishi, M.; Morita T., Fukuoka, T.; Imura T.; Kitamoto, D. (2008). Production of new types of sophorolipids by Candida batistae, J. Oleo Sci. 57, 359-369.

26. Lodder, J. (1970). The Yeast- a taxonomic study. Nort. Holand Publish, Oxford. 1, 144-176.

27. Nitschke, M.; Costa, S.G.V.A.O. (2005). Rhamnolipid surfactants: an update on the general aspects of these remarkable biomolecules . Biotechnol. 21, 1593-1600.

28. Quindós, G.; Alonso-Vargas, R.; Helou, S.; Arechavala, A.; Mazuelos, E.M.; Negroni, R. (2001). Evaluación de un nuevo medio de cultivo cromógeno (Candida ID) para el aislamiento e identificación presuntiva de Candida albicans y otras levaduras de interés médico. Rev. Iberoam. Micol. 18, 23-28. 
29. Robert, M.; Mercadé, M.E.; Bosh, M.P.; Parra, J.L.; Espuny, M.J.; Manresa, M.A.; Guinea.; J (1989). Effect of the carbon source on biosurfactant production by Pseudomonas aeruginosa 44T1. Biotechnol. Lett. 1, 871-874

30. Rufino, R.D.; Sarubbo, L.A.; Campos-Takaki.; G.M.J. (2007). Enhancement of stability of biosurfactant produced by Candida lipolytica using industrial residue as substrate. W. J. Microbiol. Biotechnol. 23, 729-734.

31. Sarubbo, L.A.; Luna.; J.M,. (2006). Production and stability studies of the bioemulsifier obtained from a new strain of Candida glabrata UCP 1002 .Electron. J. Biotechnol. 54, 68-73.

32. Shepherd, R.; Rockey, J.; Sutherland, I.W.; Roller, S. (1995). Novel bioemulsifier from microorganisms for use in food. J. Biotechnol. 40 , 207-217.

33. Singh, A.; Van Hamme, J.D.; Ward, O.P. (2007). Surfactants in microbiology and biotechnology: Part 2. Application aspects. Biotechnol. Advanc. 25, 99-121.
34. Souza- Sobrinho, H.B. (2007). Utilização de resíduos industriais como substratos de baixo custo para a produção de biossurfactante por Candida sphaerica .Pernambuco, Brasil, 99p. (M.Sc. Dissertation. Universidade Católica de Pernambuco).

35. Van der Valt, R.P.; Yarrow, D. (1984). In: kreeger-Van RIJ, N.J.W. Methods for the isolation, maintenance, classification and identification of yeast. Elseiver. Science. Pub. 45, 813-821.

36. White, T.J.; Bruns, T.; Lee, S.; Taylor, J.W. (1990). Amplification and direct sequencing of fungal ribosomal RNA genes for phylogenetics. In: PCR Protocols: A guide to methods and applications. San Diego: Academic Press, p. 315-322.

37. Youssef, K.M.; Scattergood, R.O.; Murty, K.L.; Koch. C.C. (2004). Ultratough nanocrystalline copper with a narrow grain size distribution. .Appl. Phys. Lett. 85, 929-931.

38. Yucesoy, M.; Marol, S. (2003). Performance of CHROMagar Candida and BIGGY agar for identification of yeast species. Ann Clin. Microbiol. Antimicrob. 2, 1-18. 